Prethodno priopćenje Primljen: 1. svibnja 2021.

Dorijana Škoro, mag. mus.

Prihvaćen: 20. rujna 2021.

Osnovna škola Mate Lovraka

Ul. Alojzija Stepinca, Županja

dorijanaskoro@gmail.com

https://orcid.org/0000-0003-2531-7656

Ivona Kir, mag. mus.

Glazbena škola Josipa Runjanina

Ul. Hansa Dietricha Genschera 16E, Vinkovci

ivona.kir034@gmail.com

\title{
PRIMJENA DIGITALNIH ALATA TIJEKOM AKTIVNOSTI SLUŠANJA GLAZBE U NASTAVI GLAZBENE KULTURE
}

Sažetak: Slušanje glazbe prevladavajuća je aktivnost u nastavi Glazbene kulture u kojoj učenici razvijaju kritičko mišljenje o estetski vrijednoj glazbi. Učitelji se za slušanje glazbe nerijetko koriste CD-ima i DVD-ima unatoč naglome razvoju tehnologije. Današnji su učenici digitalno pismeni, rođeni u potpuno digitaliziranome svijetu te učiteljima predstavljaju izazov u nastavi. Učenici i sustav očekuju širok raspon raznih digitalnih sadržaja-audiozapise, videozapise, animacije, fotografije i slično. Srećom, učitelj može odabrati digitalne alate kojima će se koristiti za unapređenje nastavnoga područja-slušanja glazbe. U okviru rada provedeno je istraživanje čiji je cilj utvrditi način kojim učitelji provode aktivnost slušanja glazbe te utjecaj uporabe digitalnih alata na svladavanje gradiva i motivaciju kod učenika. U istraživanju su sudjelovale četiri škole, 675 učenika općeobrazovnih škola od petoga do osmog razreda i njihovi učitelji Glazbene kulture iz Osječko-baranjske i Vukovarskosrijemske županije. Istraživanje je eksperimentalno i podijeljeno je u dvije faze - prije i poslije uporabe digitalnih alata. Dobiveni rezultati istraživanja prikazuju kako je primjenom digitalnoga alata Kahoot! olakšano usvajanje gradiva te su učenici motiviraniji tijekom slušanja glazbe. Osim toga, zamijećen je razvoj digitalnih kompetencija kod učenika i učitelja.

Ključne riječi: digitalni alati, glazbena kultura, kompetencije, slušanje glazbe 


\section{UVOD}

Nastava Glazbene kulture u Hrvatskoj mijenjala je primarna područja sukladno potrebama sustava, škole i društva. U povijesnome pregledu pronalazimo nekoliko koncepcijskih modela: aktivno muziciranje, recepcijski, integrativni (zatvoreni) i kombinirani (otvoreni) model. Djelovanjem navedenih modela i programa izmjenjivala su se glavna nastavna područja i metode poučavanja Glazbene kulture, a primjenom svakoga od novih modela i reformama učiteljima je postupno dana potpuna autonomija u koncepciji programa i sata (Rojko 2012, Svalina 2015).

Glazbena nastava nije privilegija glazbeno nadarene djece, već je namijenjena cjelokupnoj školskoj populaciji. Ona predstavlja planski utjecaj na formiranje ličnosti djeteta, pobuđivanje interesa, potreba, sposobnosti i estetskog odnosa prema glazbi. (Dobrota, 2016, str. 1)

Naglasak u nastavi Glazbene kulture općeobrazovnih škola stavlja se na susret učenika s glazbom, dok verbalne informacije proizlaze iz glazbe. Stoga danas slušanje glazbe zauzima središnje mjesto u nastavi. Cilj provođenja slušanja jest omogućiti neposredni susret učenika s glazbom s pomoću kvalitetnih audiozapisa i videozapisa. Sims (1990) u svojemu radu ističe da odabrane glazbene primjere treba reproducirati s kvalitetnih uređaja što nam kontinuirani razvoj tehnologije i omogućava. Uz kvalitetnu opremu smatra da je važan i odabir skladbi čiju duljinu treba prilagoditi dobi učenika. No iako otvoreni model donosi slobodu odabira sadržaja u obrazovnome sustavu, učitelji nailaze na poteškoće u pristupu i odabiru toga sadržaja, ali i u pronalaženju kvalitetnih glazbenih primjera. (Nastavni plan i program za osnovnu školu 2006, NOK 2010)

Milinović (2018) navodi da je glazba modernizacijom tehnologije postala pristupačnija nego ikad prije. Učenicima, ali i učiteljima omogućen je pristup većini zvučnih sadržaja putem raznih elektroničkih uređaja, ali i kvalitetno reproduciranje istih.

Vidulin i Martinović (2015) u svojemu radu navode kako slušanje glazbe i upoznavanje učenika s vrijednim umjetničkim djelima nije jednostavan zadatak. Smatraju da je slušanje kao aktivnost polagan, postupan i dugotrajan proces koji treba pozorno pedagoško-didaktičko-metodički osmisliti, ali i jasno strukturirati te precizno voditi. Njegovom dobrom pripremom i vođenjem učenicima se na kvalitetan način pruža mogućnost upoznavanja umjetničke i folklorne glazbe, ali i ostalih popularnih glazbenih žanrova uz koje će upoznati svjetsku i nacionalnu glazbenu kulturu. Osim glazbenoga ukusa takvim se pristupom učenicima oblikuje i kulturni identitet. 
Kako učenike motivirati za slušanje glazbe, a da ono bude aktivno? Prije slušanja ne treba govoriti o glazbi, već glazbi treba dati priliku da ona sama govori o sebi. (Šulentić Begić i Birtić, 2012, str. 5)

Rojko (2012) smatra da je vrlo važno pobuditi učenikovu pozornost na aktivno slušanje popraćeno zadatcima usmjerenima na glazbene elemente; izvođački sastav, glazbeni oblik, tempo, melodiju, ritam ili dinamiku, postavljenima neposredno prije slušanja. Pravilnim metodičkim postupcima treba provoditi višekratno aktivno, a ne pasivno slušanje glazbe.

U pasivnome slušanju glazba nije u središtu pozornosti već je popratna pojava drugim radnjama. S takvim načinom slušanja često se susrećemo u svakodnevnome životu (u vožnji, trgovačkim centrima ili kod kuće) i u literaturi ga često pronalazimo pod nazivom nesvjesno slušanje glazbe. Takav pristup slušanju treba izbjegavati jer primjenom samo aktivnoga slušanja glazbe učenici stječu znanja o glazbeno-izražajnim sastavnicama, različitim razinama organizacije glazbenih djela te uče kako razumjeti, vrednovati i istraživati novu glazbu. (Rojko, 2012)

\section{SUVREMENA ŠKOLA}

U povijesnome presjeku razvoja škole jasno je da je zbog potrebe i razvoja društva staru školu zamijenila nova škola, a novu školu zahvaljujući ubrzanome razvoju tehnologije zamjenjuje suvremena škola.

Suvremena škola treba biti u kontinuiranom razvoju i mijenjanju, baš kao $i$ učitelj koji je svojim djelatnim bićem mijenja, kako bi nove generacije mogla pripremiti za nesigurnost postmodernog doba. (Stoil i Fink 2000, prema Mlinarević i Borić, 2007, str. 422)

Suvremena škola polazi od stajališta da je učenik glavni čimbenik nastave radi kojega se organizira i oblikuje nastavni proces. Matijević i Topolovčan (2017) navode da se suvremena nastava zasniva na međusobnoj komunikaciji učitelja i učenika koji su temeljni subjekti nastavnoga procesa. Zajedničkim radom teže ostvarenju kognitivnih, afektivnih i psihomotoričkih ciljeva, ali i zadataka takve nastave (prikaz suvremene nastave didaktičkim trokutom na Slici 1).

U suvremenoj školi je promijenjena uloga učitelja kao predavača kojeg je zagovarala tradicionalna nastava, u ulogu organizatora, vođe, mentora i suradnika. (Zrilić i Marin, 2019, str. 389)

Uz ciljeve i zadatke navode činjenicu da je učenik onaj koji prima utjecaje od nastavnika da bi učenjem i nastavom postao važan faktor odgojno-obrazovnoga procesa. Također, Matijević i Toplovčan (2017) navode kako je za suvremenu školu svojstvena stalna zamjena pozicija nastavnika i učenika, ovisno o aktualnoj tematici. 
Škola sutra neće biti samo izvršitelj različitih obrazovnih programa nego prvenstveno organizator, poticatelj i koordinator njihove realizacije. (Puževski, 2002, str. 121)

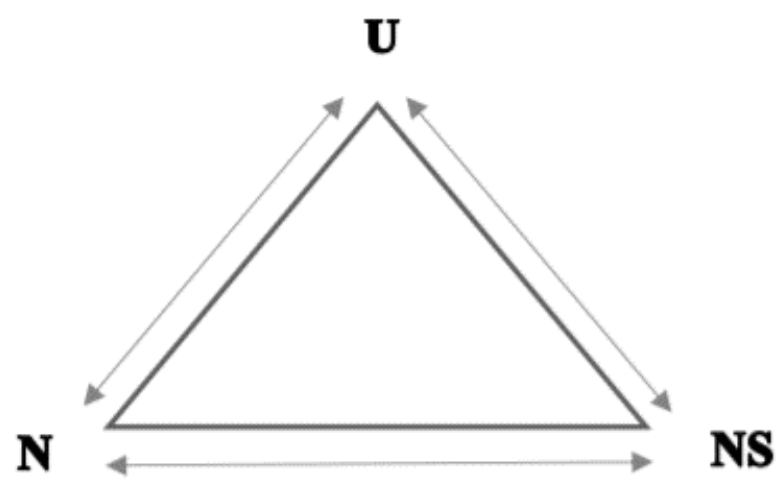

Slika 1. Didaktički trokut suvremene škole (Poljak 1990, prema Vurušić 2019, str. 4.

Preuzeto s file://C:/Users/Korisnik/Downloads/vurusic_m_0069051027.pdf)

Poljak (1990) u svojemu radu objašnjava da je ubrzan razvoj tehnologije jedan od glavnih faktora koji je utjecao na proširenje didaktičkoga trokuta $u$ didaktički četverokut (prikaz suvremene nastave didaktičkim četverokutom na Slici 2). U četverokut se dodaje novi element - tehnologija - koja se sjedinjuje s već prethodno utemeljenim elementima. Takvim proširenjem tehnologija postaje neizostavni dio nastavnoga procesa, proširuje vidike nastave pružajući učenicima uvid u elemente koje je nemoguće vidjeti ili neposredno doživjeti.

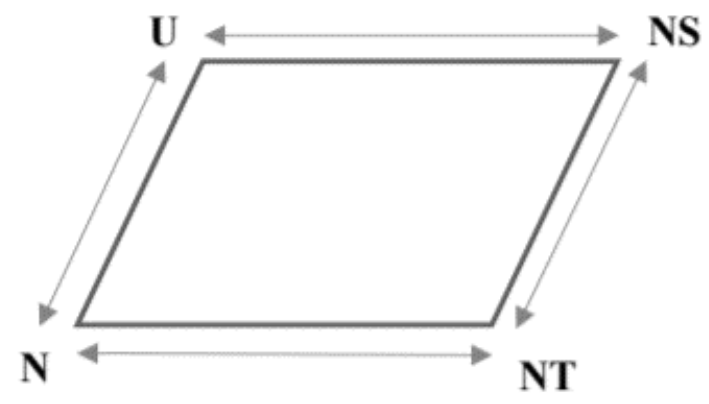

Slika 2. Didaktički četverokut (Poljak 1990, prema Vurušić 2019, str. 4. Preuzeto s file://C:/Users/Korisnik/Downloads/vurusic_m_0069051027.pdf) 


\section{MODERNA TEHNOLOGIJA U NASTAVI - DA ILI NE?}

Uvođenjem moderne tehnologije u nastavni proces ostvaruju se i preduvjeti za multimedijsku nastavu. Bognar i Matijević (2005, prema Matijević i Topolovčan 2017) pod pojmom multimedijska nastava podrazumijevaju uporabu dvaju ili više različitih medija kojima se koristi u nastavi uz odgovarajuće strategije učenja. Takva nastava uključuje digitalne medije kao što su pametni telefoni, tableti, računala i laptopi uz sve popratne digitalne alate. Korištenjem digitalnih medija u nastavi proces učenja i poučavanja više se toliko ne veže uz školu već se događa i izvan nje (kod kuće, u parku, na izletu, s prijateljima). Takvim pristupom na zanimljiv način može se povezati izvanškolske sadržaje s nastavnim procesom što je ujedno i jedan od ciljeva suvremene škole.

„Svakako je velika blagodat mogućnost pohrane ogromne količine podataka u uglavnom oku nevidljivoj virtualnoj memoriji. K tome, digitalni podatci mogu se vrlo lako i brzo obrađivati, kreirati i mijenjati, a multimedija pruža velike mogućnosti raznih dojmljivih (dinamičnih) prikaza i simulacija bez opasnosti od ozljede ili materijalne štete. Nadalje, ako postoji ikakva logična povezanost, računalo je može prepoznati te primijeniti, što omogućuje jednostavne analize, sinteze, izoliranje (faktora) ili isticanje." (Novosel, 2017, str. 66)

March (2006) navodi kako uz digitalne medije učenici mogu učiti što žele, kada žele i gdje žele. Shodno tome možemo zaključiti da je uporaba moderne tehnologije i digitalnih medija u nastavi poprilično poželjna. Učenici s pomoću navedenih medija i brojnih materijala koji su im svakodnevno dostupni mogu sami učiti i od ranije školske dobi. Takva razmišljanja navode nas na pitanja o procesu samoobrazovanja. Je li moguće provesti samoobrazovanje u nastavi Glazbene kulture i Mogu li učenici rane i starije školske dobi uspješno usvojiti nastavne sadržaje Glazbene kulture uz pomoć digitalnih alata i medija? No valja napomenuti da uz primjenu moderne tehnologije i medija u nastavi učitelji neprestano trebaju proučavati, usustavljivati i objašnjavati materijale, ali i biti spremni za izvođenje takve nastave kako bi se osigurala najveća moguća učinkovitost procesa učenja. (Matijević i Topolovčan, 2017)

\section{DIGITALNA TEHNOLOGIJA I ALATI}

Kao što napredak i razvoj tehnologije utječe na društvo i okruženje, njezin utjecaj jasno je vidljiv i u promjeni općeobrazovnoga procesa. Uporaba digitalnih medija sve je učestalija u nastavnome procesu upravo zbog različitih digitalnih alata koji se svakodnevno nameću učiteljima i nude brojne raznolike aktivnosti sa svrhom poboljšanja nastavnoga procesa. Vještine i sklonosti korištenja tehnologije rezultat su odrastanja u tehnološki zasićenome okruženju u kojemu tehnološke naprave poput računala, mobiteli i općenito zasloni - postaju sastavni dio života. (Lasić-Lazić, Špiranec i Banek 2012) 
U priručniku Digitalne tehnologije kao potpora praćenju $i$ vrednovanju iz 2018. godine navodi se kako primjena digitalnih tehnologija u nastavnome procesu povećava motivaciju i koncentraciju učenika. Uz to tehnologija i alati potiču njihovu samostalnost i aktivnost, ostvaruju mnoge ciljeve, zadatke, ishode te elemente nastave. S pomoću digitalnih alata učitelji se na drugačiji i inovativniji način pripremaju za nastavu te, ako žele, digitalnim se alatima mogu koristiti u procesu (samo)praćenja i (samo)vrednovanja nastave, osobnoga rada i napretka, ali i napretka učenika. Dosadašnja istraživanja pokazala su da je vrednovanje učeničkih postignuća jedno od najvažnijih, najosjetljivijih i poprilično zahtjevnih područja rada učitelja. Digitalna tehnologija pruža učiteljima mogućnost aktivnoga uključivanja učenika u praćenje i vrednovanje vlastitoga napretka. Učenik postiže bolju kontrolu nad vlastitim učenjem i znanjem i preuzima odgovornost za njega.

Budući da sva djeca ne uče na isti način, uvođenje nastavne tehnologije u glazbenu nastavu osigurava različite mogućnosti učenja i pomaže da učenik razvije kreativno mišljenje, rješavanje problema, komunikaciju i sposobnosti timskog rada. (Dobrota, 2015, str. 4)

Zbog prednosti uporabe digitalnih alata u nastavi nametnula se ideja uporabe digitalnoga alata u Glazbenoj kulturu, konkretno u aktivnosti slušanja glazbe. Desetljećima se princip izvođenja te aktivnosti nije promijenio, a izvodi se tako što se prije višekratnoga slušanja glazbenoga djela učenicima zadaju primjereni zadatci kako bi aktivno slušali glazbu. Odgovori se zapisuju u kajdanke ili bilježnice, a učitelj po vlastitome odabiru bilježi odgovore učenika na ploču ili ih prezentira na projektnome platnu projektorom i nekim od računalnih programa. (Svalina 2015, prema Dobrota 2012) Isti postupak moguće je primijeniti i u nekim od digitalnih alata, na zanimljiv i učinkovitiji način, a za potrebe ovoga istraživanja odabran je digitalni alat Kahoot!.

\section{KAHOOT!}

Kahoot! je besplatan interaktivni digitalni alat namijenjen brzoj i jednostavnoj izradu testova/kvizova za provjeru znanja, upitnika i diskusija. Na internetu se pojavljuje u ožujku 2013. godine i vrlo brzo postaje jedan od najomiljenijih digitalnih alata učenika i učitelja. Digitalnomu alatu Kahoot! pristupa se na mrežnoj adresi https://kahoot.it/. (Groznik 2021, Tomaš 2018)

Za primjenu digitalnih alata u radu s učenicima, nužno je ostvariti tehničke preduvjete, a oni podrazumijevaju računalo i projektor te računala, prijenosna računala, tablete ili mobilne uređaje za učenike. Pitanje se učenicima prikazuje projektorom najmanje 5 sekundi nakon čega se prikazuju ponuđeni odgovori uz odbrojavanje vremena. Pitanja mogu biti zatvorenoga tipa dvostrukoga ili višestrukog odabira i mogu se određivati točnosti tvrdnje. Koncept pitanja može sadržavati samo tekst i primjerenu sliku ili fotografiju, a u novijoj inačici 
alata može se postaviti i zvučni videozapis s YouTubea. Upravo ta mogućnost umetanja glazbenoga djela u kviz nametnula je ideju za unapređenjem procesa slušanja glazbe u glazbenoj nastavi. (Negulić 2015)

U samim početcima razvoja alata na zaslonu uređaja kojima se koriste učenici nisu se prikazivala pitanja i tekst odgovora, nego samo četiri polja različite boje i različitoga oblika kako je prikazano. Zahvaljujući trajnomu razvoju alata danas učenici dok odgovaraju na pitanja mogu vidjeti pitanje, ali i odgovor $u$ odgovarajućim različitim bojama. Učenici ne mogu svojim uređajima kontrolirati tijek aktivnosti u alatu Kahoot! ili preskakati pitanja. Samo učitelj može odrediti automatsko ili ručno izmjenjivanje pitanja, što je još jedna od prednosti toga alata.

U priručniku Digitalne tehnologije kao potpora praćenju i vrednovanju iz 2018. godine navodi se da, s obzirom na način praćenja i vrednovanja učeničkih rezultata, digitalni alat Kahoot! potiče natjecateljski duh učenika i ostvaruje elemente igre u stvarnome vremenu. Stoga autori priručnika preporučuju uporabu toga alata u motivacijskim dijelovima nastavnih sati. Pozitivan utjecaj alata na motivaciju učenika potvrđuje istraživanje skupine autora Nikolić, Lolić, Havzi, Spasojević i Stefanović (2021) koji su ispitivali utjecaj alata Kahoot! na motivaciju studenata na Fakultetu tehničkih nauka, Novi Sad, Srbija. Čak 81,4 $\%$ studenata procijenilo je pozitivan utjecaj na osobnu motivaciju dok se 18,6 $\%$ studenata ne slaže s navedenom tvrdnjom.

Kao nedostatak alata, autori priručnika iz 2018. godine ističu onemogućeno dugotrajno praćenje rezultata učenika. Rezultati učenika prikazuju se nakon svakoga pitanja; koliko je učenika odabralo koji odgovor i na kraju aktivnosti prikazuje se konačan poredak gdje je prikazano pet učenika s najviše bodova. Po završetku aktivnosti alat učitelju nudi mogućnost pohranjivanja rezultata učenika u Excelu u kojemu je prikaz točnih i netočnih odgovora učenika. Uz to novija verzija alata Kahoot! učitelje upozorava na pitanja koja su imala manji postotak točnih odgovora $\mathrm{i}$ ona $\mathrm{s}$ najvećim postotkom odgovora što učitelju pruža automatsku povratnu informaciju o usvojenosti gradiva obrađenome u kvizu.

\section{CILJ I HIPOTEZE ISTRAŽIVANJA}

Cilj je ovoga istraživanja ispitati važnost područja slušanja glazbe u nastavi Glazbene kulture, utvrditi način kojim učitelji provode aktivnost slušanja glazbe, stavove učenika prema glazbi s kojom se susreću svakodnevno na nastavi Glazbene kulture i može li se učenike motivirati na aktivnije slušanje glazbe s pomoću digitalnoga alata. 
U skladu s navedenim ciljevima istraživanja postavljene su sljedeće hipoteze:

H1: Učenici vole slušati glazbu.

H2: Učenici kod kuće ne slušaju glazbu koju upoznaju na nastavi Glazbene kulture.

H3: Učitelji Glazbene kulture nerijetko se koriste digitalnim alatima u nastavi.

H4: Učitelji Glazbene kulture smatraju slušanje glazbe jednim od najvažnijih područja u nastavi.

H5: Učenici aktivnije sudjeluju u nastavi Glazbene kulture uz primjenu digitalnih alata.

H6: Učenici aktivnije slušaju glazbu uz primjenu digitalnoga alata.

H7: Učitelji se samostalno obrazuju za uporabu digitalnih alata.

Zadatci prve etape istraživanja učenika bili su:

1. utvrditi mišljenje učenika o slušanju glazbe na nastavi Glazbene kulture

2. utvrditi njihov stav o uporabi digitalnih alata tijekom upoznavanja s glazbom.

Zadatci prve etape istraživanja učitelja bili su:

1. ispitati važnost nastavnoga područja slušanja glazbe u nastavi Glazbene kulture

2. ispitati učestalost i način provođenja slušanja glazbe

3. ispitati digitalne kompetencije kao pripremu za drugu fazu istraživanja.

Zadatci druge etape istraživanja učenika bili su:

1. ispitati utjecaj digitalnog alata na njihovu motivaciju za aktivnije slušanje glazbe

2. ispitati utjecaj digitalnog alata na njihovu motivaciju za aktivnije sudjelovanje u nastavnom procesu

3. utvrditi mišljenje učenika o češćoj uporabi digitalnog alata tijekom upoznavanja s glazbom.

Zadatci druge etape istraživanja učitelja bili su:

1. ispitati gubi li slušanje glazbe na važnosti ukoliko ga se implementira $\mathrm{u}$ digitalni alat

2. ispitati važnost digitalnih kompetencija

3. ispitati utjecaj digitalnog alata na proces nastave. 


\section{METODOLOGIJA}

\section{SUDIONICI}

Istraživanje je provedeno u dvjema fazama, tijekom siječnja i veljače 2021. godine u četirima osnovnim školama u Osječko-baranjskoj i Vukovarskosrijemskoj županiji. U istraživanju je sudjelovalo 675 učenika općeobrazovnih škola od petoga do osmog razreda te njihove tri učiteljice Glazbene kulture od kojih je jedna zbog nedostatka satnice zaposlena u dvije općeobrazovne škole. Ispitanicima je sukladno etičkim principima objašnjena svrha provođenja istraživanja, zajamčena anonimnost te su zamoljeni da iskreno i precizno odgovaraju na pitanja u objema fazama.

\section{INSTRUMENT I POSTUPAK ISPITIVANJA}

Za potrebe istraživanja izrađena su dva anketna upitnika za učenike općeobrazovne škole i dva anketna upitnika za učiteljice Glazbene kulture. U prvome dijelu anketnih upitnika namijenjenih učenicima nalaze se pitanja koja se odnose na sociodemografska obilježja učenika (mjesto škole, spol i razred). Struktura uzorka učenika prikazana je u tablici 1. U drugome dijelu upitnika (za učitelje i učenike) sastavljena različita su pitanja koja se odnose na slušanje glazbe u nastavi Glazbene kulture, prije i nakon uporabe digitalnoga alata Kahoot!.

Tablica 1. Struktura uzorka učenika $(\mathrm{N}=675)$

\begin{tabular}{ccc}
\hline obilježje & f & \% \\
\hline spol & & \\
muški & 323 & $47,85 \%$ \\
ženski & 352 & $52,15 \%$ \\
razred & & \\
5. & 134 & $19,85 \%$ \\
6. & 167 & $24,74 \%$ \\
7. & 173 & $25,63 \%$ \\
8. & 201 & $29,78 \%$ \\
mjesto škole & & \\
grad & 366 & $54,22 \%$ \\
predgrađe & 250 & $37,04 \%$ \\
selo & 59 & $8,74 \%$ \\
ukupno & 675 & \\
\hline
\end{tabular}

Upitnik namijenjen učiteljicama Glazbene kulture, isto kao i kod učenika, u prvome dijelu sadrži pitanja o sociodemografskim obilježjima (spol, godine radnoga iskustva, stručna sprema i mjesto škole) Struktura uzorka učiteljica 
prikazana je u tablici 2. Drugi dio sadrži pitanja o opremljenost učionica u kojima svakodnevno izvode nastavu, uporabi digitalnih alata, načinu izvođenja aktivnosti slušanja glazbe, iznošenju stavova o slušanju glazbe klasičnom metodom i s pomoću digitalnoga alata Kahoot! prije istraživanja i nakon njega. Također prije samoga početka istraživanja utvrđena je zadovoljavajuća opremljenost učionica (računalo, internet, projektor, projektno platno, zvučnici, tableti za učenike) i povoljni uvjeti za provođenje prve i druge faze.

Tablica 2. Struktura uzorka učiteljica $(\mathrm{N}=3)$

\begin{tabular}{ccc}
\hline obilježje & f & \% \\
\hline spol & & \\
ženski & 3 & $100 \%$ \\
godine radnog & & \\
iskustva & & \\
$0-10$ & 1 & $33,33 \%$ \\
$21-30$ & 2 & $66,67 \%$ \\
stručna sprema & & \\
$\quad$ visoka & 3 & $100 \%$ \\
mjesto škole & & \\
$\quad$ grad & 2 & $66,67 \%$ \\
predgrađe & 1 & $33,33 \%$ \\
selo & 1 & $33,33 \%$ \\
ukupno & 3 & \\
\hline
\end{tabular}

U prvoj fazi istraživanja ispitani su učenici $(\mathrm{N}=675)$ i učiteljice Glazbene kulture $(\mathrm{N}=3)$ anketnim upitnicima krajem siječnja 2021. godine. Upitnik namijenjen učenicima sadržavao je šest pitanja zatvorenoga tipa dvostrukoga i višestrukog odabira. Upitnik namijenjen učiteljicama Glazbene kulture sadržavao je 18 pitanja zatvorenoga tipa dvostrukoga ili višestrukog odabira i pitanja za iznošenje stava o važnosti provođenja slušanja glazbe konstruirana po uzoru na Likertovu skalu (1 - ne mogu procijeniti, 2 - ne slažem se, 3 - slažem se, 4 - uglavnom se slažem i 5 - u potpunosti se slažem).

Druga faza istraživanja provedena je u veljači 2021. godine. Prije samoga početka održan je sastanak s učiteljicama Glazbene kulture na kojemu su odabrane nastavne jedinice za njihove razrede (obrada glazbala, glazbenih vrsta, sastavnica i oblika, pjevačkih glasova, glazbeno-stilskih razdoblja te tradicijska glazba Hrvatske i drugih zemalja). Uz to omogućeno im je i detaljnije upoznavanje s digitalnim alatom Kahoot! kako bi se druga faza istraživanja provela bez većih poteškoća. Zahvaljujući kurikulskoj reformi Škola za život, učenicima su početkom školske godine osigurani tableti, stoga nisu morali u školu donositi svoje privatne uređaje kako bi se koristili digitalnim alatom Kahoot!. Druga faza sveukupno je trajala tri tjedna, tj. tri 
školska sata u svakome razredu, od kojih se dva tjedna slušala glazba digitalnim alatom, a posljednji tjedan ispitano je mišljenje učenika i učitelja o slušanju glazbe na nastavi Glazbene kulture nakon uporabe digitalnoga alata.

\section{REZULTATI I RASPRAVA}

U prvoj fazi na pitanje kojim se utvrđuje vole li učenici slušati glazbu njih $87 \%$ odgovara pozitivno dok samo $13 \%$ učenika odgovara negativno. Dobiveni rezultat može pozitivno potvrditi prvu postavljenu hipotezu da učenici vole slušati glazbu, ali i nadovezati se na istraživanje Šuletić Begić (2013) u kojem je $100 \%$ učenika odgovorilo da voli slušati glazbu. Shodno tome zaključujemo da učenici vole slušati glazbu, no nameće se pitanje vole li slušati glazbu koju su upoznali na nastavi Glazbene kulture ili onu glazbu koju osobno biraju.

Na pitanje slušaju li učenici glazbu koju su upoznali na nastavi Glazbene kulture kod kuće dobiveni su poražavajući rezultate. Nažalost $94 \%$ ne sluša takvu vrstu glazbe kod kuće, dok samo $6 \%$ učenika ipak cijeni umjetničku glazbu i sluša je kod kuće. Ovim rezultatom potvrđuje se i druga hipoteza ovoga rada. Gaggiolo i Lamont (2003, prema Vidulin 2013) te Hargreaves, Marshall i Tarrant (2003, prema Vidulin 2013) u svojim istraživanjima navode kako mlađa populacija preferira vrstu glazbe koja je lako dostupna i koju mogu lako razumjeti. Za takvu vrstu glazbe ne trebaju glazbeno znanje ni preveliku koncentraciju tijekom slušanja. Zbog takvoga stava možemo zaključiti da mladi ne žele slušati umjetničku glazbu, već glazbu koja im se obraća izravno; takva glazba navodi mlade kako se trebaju nositi s osjećajima u životu, čemu treba težiti i kako treba izgledati. Skupina autora Škojo, Radočaj-Jerković i Milinović (2016) navodi kako suvremena sredstva za produkciju i reprodukciju zvuka upravo pridonose populariziranju takve vrste glazbe i omogućuju njezino masovno širenje, čine ju sveprisutnom i lako dostupnom svima.

No ipak ne smijemo gubiti nadu. Šulentić Begić i Begić (2013) proveli su istraživanje u osječkoj I. gimnaziji, a rezultati pokazuju kako učenici ne odbijaju umjetničku glazbu, iako većina njih ne sluša takvu glazbu u slobodno vrijeme. Od svih sudionika u istraživanju njih 71,56 \% iskazalo je stav da voli slušati umjetničku glazbu na nastavi Glazbene umjetnosti, no takva glazba im najčešće nije prvi izbor.

Treću hipotezu potvrđuju rezultati koji pokazuju da se ispitane učiteljice Glazbene kulture $(\mathrm{N}=3)$ na svakome satu ili jednom u dva tjedna koriste digitalnim alatima u nastavi. Ako su potvrdno odgovorile na postavljeno pitanje, $\mathrm{u}$ anketi su zamoljene da navedu digitalne alate $\mathrm{s}$ kojima su se već prije susretale u nastavi. Učiteljice su nabrojile sljedeće alate: Wizer, Wordwall, Kahoot!, Edpuzzle, Mentimeter, Lino it i Canva. 
Analizirajući popis alata s kojima su se već susrele u nastavi, može se primijetiti da on nije kratak te da su ispitane učiteljice poprilično informatički pismene i uglavnom spremne za digitalne izazove u nastavi 21. stoljeća.

Anketnim upitnikom utvrđeno je da učiteljice izvode aktivnost slušanja glazbe na standardni metodički način u kojemu nakon pomno odabranih reprezentativnih skladbi pripreme zadatke za aktivno slušanje glazbe. Osmišljeni zadatci služe im kao priprema učenika za aktivno slušanje glazbe, a u njima najčešće od učenika traže da prepoznaju i odrede sljedeće glazbene sastavnice: izvođači, tempo, dinamika, mjera, slog, značajke melodije, boja tona, vrsta glazbenoga djela, ritam itd., ili neke druge parametre koji su uključeni u glazbenome djelu. Uz to učiteljice su pitane kojim se nastavnim sredstvima koriste u izvođenju aktivnosti slušanja glazbe. Odgovori vidljivi u Grafu 1 i pokazuju vrlo pozitivan rezultat jer se učiteljice ne koriste samo jednim izvorom već ih kombiniraju nekoliko kako bi njihova nastava, a i slušanje glazbe bili zanimljiviji učenicima.

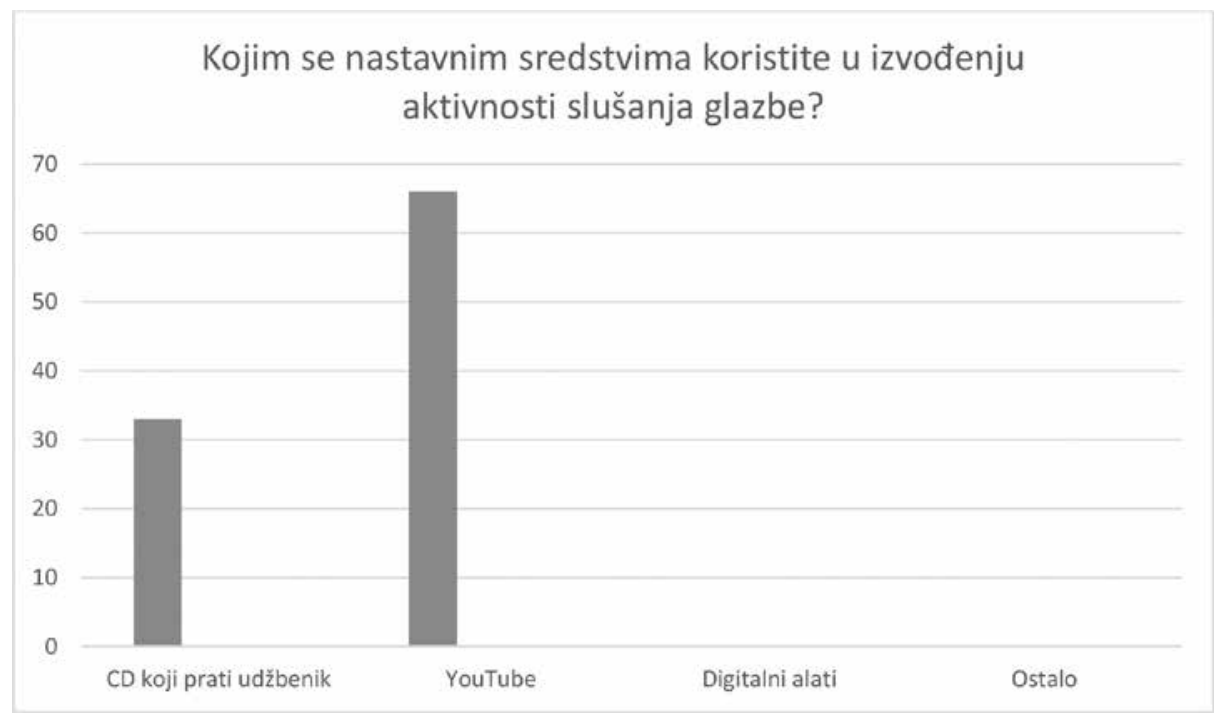

Grafikon 1. Uporaba nastavnih sredstava

U pitanju konstruiranome po uzoru na Likertovu skalu učiteljice su iznosile stav o važnosti provođenja slušanja glazbe. U potpunosti se slažu (100 \%) sa sljedećim tvrdnjama:

1. Slušanje glazbe najvažnije je područje u nastavi Glazbene kulture.

2. Slušanje glazbe temelj je za sva ostala područja u nastavi Glazbene kulture. 
3. Slušanje glazbe mora biti aktivno i popraćeno jasnim uputama kako bi učenici znali na koje se glazbene sastavnice trebaju fokusirati.

4. Važno je usmjeriti učenike na aktivno slušanje u što ranijoj školskoj dobi.

5. Tijekom slušanja treba izbjegavati pasivan način slušanja.

6. Slušanjem različitih vrsta glazbe učenike potičemo na razumijevanje $i$ interkulturalizam.

7. Provođenjem aktivnosti slušanja glazbe učenici će naučiti vrednovati glazbu.

Navedenim stavovima potvrđuje se hipoteza da učitelji smatraju slušanje glazbe jednim od najvažnijih područja u nastavi Glazbene kulture. Preostale tvrdnje u kojima nema stopostotnoga podudaranja u stavovima nalaze se u daljnjemu tekstu, u Tablici 3.

Tablica 3. Rezultati preostalih stavova učitelja u kojima nema stopostotne podudaranosti

\begin{tabular}{llll}
\hline Tvrdnje & $\begin{array}{l}\text { U potpunosti } \\
\text { se slažem (f) }\end{array}$ & $\begin{array}{l}\text { Uglavnom se } \\
\text { slažem (f) }\end{array}$ & $\begin{array}{l}\text { Slažem se } \\
\text { (f) }\end{array}$ \\
\hline Učenici vole slušati glazbu & 1 & 1 & 1 \\
$\begin{array}{l}\text { Slušanjem glazbe učenici stječu znanja } \\
\text { o glazbeno-izražajnim sastavnicama }\end{array}$ & 2 & 1 & \\
$\begin{array}{l}\text { Provođenjem aktivnosti slušanja } \\
\text { glazbe učenici će naučiti razumjeti } \\
\text { glazbu }\end{array}$ & 2 & 1 & \\
ukupno & 3 & & \\
\hline
\end{tabular}

Iz prve faze još valja izdvojiti rezultat koji u potpunosti (100 \%) potvrđuje sedmu hipotezu da se učitelji samostalno obrazuju za uporabu digitalnih alata. Zahvaljujući izdavačkim kućama i raznim projektima u Hrvatskoj, učitelji danas imaju mogućnost sudjelovati u raznim mrežnim seminarima u Hrvatskoj, ali i svijetu, na kojima mogu saznati novitete u nastavi, a i raspoloživim digitalnim alatima. Nažalost velika većina digitalnih alata još je uvijek na engleskome jeziku, stoga, ako se želi koristiti nekim od alata, poznavanje engleskoga jezika neupitno je. Uz mrežne seminare učitelji na županijskim ili državnim stručnim skupovima imaju priliku primjerima dobre prakse ili kolegijalnom podrškom naučiti kako se pravilno koristiti digitalnim alatima u nastavi, no još uvijek u nedovoljnoj mjeri.

Priprema nekog multimedijskog projekta za obrazovanje je izuzetno složen posao za koji je potreban timski rad niza stručnjaka - od stručnjaka za gradivo (profesor, nastavnik, predavač...), preko instrukcijskih dizajnera čija je uloga 
prilagodba klasičnih metoda podučavanja za novi medij uz uvažavanje svih njegovih prednosti i mana, do razvojnih stručnjaka različitih profila (grafički dizajneri, stručnjaci za alate, programeri, audio i video tim itd). Pri tome, razvoj tehnologije i alata ide u smjeru pojednostavljivanja njihovog korištenja na način da oni postaju dostupni sve širem krugu ljudi koji se bave edukacijom, bez obzira na informatičko predznanje. (Matasić i Dumić, 2012, str. 145)

Druga faza istraživanja započinje primjenom digitalnoga alata Kahoot! u redovnoj nastavi tijekom dvaju tjedana, tj. u dvjema različitim nastavnim jedinicama u dvama satima. Nakon novoga načina slušanja glazbe u glazbenoj nastavi slijedila je posljednja etapa druge faze istraživanja u kojoj su učenicima i učiteljicama podijeljeni drugi anketni upitnici. Rezultati se odnose na mišljenje učenika i učitelja o slušanju glazbe nakon uporabe digitalnoga alata.

Na pitanje o tome je li slušanje glazbe na nastavi Glazbene kulture zanimljivije uz Kahoot! čak 96,59\% $(\mathrm{N}=625)$ učenika odgovara potvrdno dok samo $3,41 \%(\mathrm{~N}=23)$ učenika smatra da takav način slušanja glazbe nije zanimljiv. Slični rezultati dobiveni su i na pitanjima koja se odnose na motivaciju učenika tijekom nastave Glazbene kulture. Digitalni alat Kahoot! motivirao ih je na aktivnije slušanje glazbe, aktivnije sudjelovanje u nastavi te je unio pozitivnoga natjecateljskog duha u sam nastavni proces. Pozitivni rezultati druge faze istraživanja potvrđuju i petu postavljenu hipotezu koja navodi da učenici aktivnije sudjeluju u nastavi uz primjenu digitalnih alata. Dobivene rezultate i hipotezu potvrđuje istraživanje skupine autora Nikolić, Havzić, Narandžić, Dakić i Janković (2020) u kojem su ispitivali integraciju digitalnog alata Kahoot! u visokoškolskom obrazovanju. Analizom rezultata zaključuju da je 78 \% studenata integracijom Kahoot! alata potaknuto na aktivnije sudjelovanje u nastavi. Također, vidljiv je utjecaj na motivaciju studenata te natjecateljskog duha.

Iz anketnoga upitnika namijenjenoga učiteljicama u drugoj fazi najviše se ističe pitanje otvorenoga tipa: Kakav utjecaj primjećujete u aktivnosti učenika na nastavi Glazbene kulture nakon uporabe digitalnoga alata. Učiteljice uglavnom odgovaraju pozitivno što donekle potvrđuje šestu navedenu hipotezu u radu (Učenici aktivnije slušaju glazbu uz primjenu digitalnih alata). Navode sljedeće odgovore:

- Utjecaj digitalnog alata poprilično pozitivan $i$ vidljiv čak nakon prvog sata.

- Učenici aktivnije sudjeluju u nastavi.

- Učenici lakše usvajaju gradivo i bez obzira na odabranu vrstu glazbe.

- Učenici slušaju glazbu aktivnije.

- Učenicima je uz Kahoot! zanimljivija nastava Glazbene kulture.

- Učenici lakše odgovaraju na pitanja ukoliko imaju više ponuđenih odgovora (određivati glazbene sastavnice, dijelove skladbe ili izvođačke sastave).

- Učenici, ali i učiteljice razvijaju digitalne kompetencije. 
No ne treba zanemariti i nedostatke digitalnoga alata. Učiteljice smatraju da Kahoot! u izvođenju aktivnosti slušanja glazbe može navesti učenike na pasivan način slušanja glazbe zato što učenici svoju pozornost usmjeravaju na brzinu odgovaranja i bodovnu listu na kraju aktivnosti, a ne na samo glazbeno djelo. Pasivan način slušanja glazbe uz digitalni alat može se izbjeći ako je učitelj prije vođenja aktivnosti izradio dobru pripremu i učenicima prije slušanja zadao jasne upute.

Brojna istraživanja pokazuju da je za potpuni doživljaj djela i uočavanje svih glazbenih sastavnica potrebno višekratno slušanje. Gilliland i Moore (Rojko 2012) u svojemu istraživanju došli su do spoznaja da s ponavljanjem slušanja klasična djela postaju omiljenija kod učenika za razliku od zabavnih djela. Vidulin-Orbanić (2002) ističe da se višekratnim slušanjem u nastavi mogu zapaziti prikrivene pojedinosti glazbenog djela koje se tijekom prvoga slušanja nisu mogle slušno uočiti. Višekratno slušanje može se postići i uz pomoć digitalnoga alata Kahoot!. U osmišljavanju pitanja nudi se mogućnost odabira trajanja glazbenoga primjera, a odabrani dio skladbe može se poslušati više puta uz različita pitanja.

Na posljednje pitanje u drugome anketnom upitniku Smatram da bi se Kahoot! trebao češće upotrebljavati za aktivnost slušanja glazbe u nastavi Glazbene kulture učenici i učiteljice odgovaraju pozitivno. Čak 94,22 \% (N =636) učenika odgovara potvrdno dok samo 5,77 \% $(\mathrm{N}=39)$ učenika ne želi češću uporabu navedenoga digitalnog alata. Sve učiteljice Glazbene kulture odgovaraju potvrdno (rezultati u postotcima nalaze se u Grafu 2). Dobrota (2015, prema Rudolph i sur., 2005) smatra kako moderna tehnologija ima veliku primjenu u glazbenom obrazovanju. Istraživanja koja navodi pokazuju da kada učenici postaju aktivniji u nastavnom procesu stječu samopouzdanje, uče na mnogo učinkovitiji način i motivirani su za nastavak učenja. No napominje kako primjena te iste tehnologije u glazbenoj nastavi mora biti isplaniran metodički postupak jer neumjerene primjene neće značajnije utjecati na glazbeni razvoj djeteta.

$S$ obzirom na način praćenja i vrednovanja učeničkih rezultata, digitalni alat Kahoot! potiče natjecateljski duh učenika i ostvaruje elemente igre u stvarnome vremenu. Stoga se primjena Kahoota! preporučuje u motivacijskim dijelovima nastavnih sati. (Tomaš, 2018, str. 26). 
D. Škoro, I. Kir: Primjena digitalnih alata tijekom aktivnosti slušanja glazbe ...

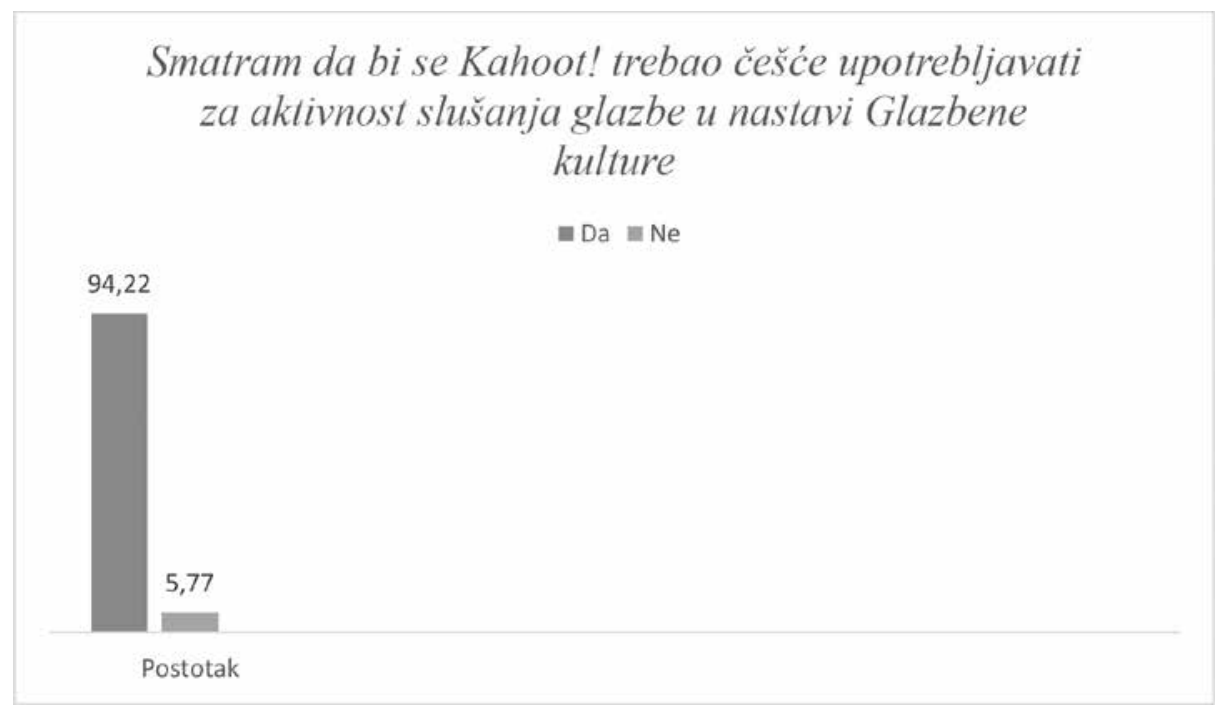

Grafikon 2. Rezultati mišljenja učenika na posljednje pitanje druge ankete

\section{ZAKLJUČAK}

Promjene u načinu poučavanja novih i već digitalno pismenih generacija neophodne su i stvaraju mogućnost za implementiranje novih tehnika kao što je uporaba raznih digitalnih alata. Digitalnim alatima nastava Glazbene kulture, ali i drugih nastavnih predmeta, može se dodatno obogatiti i učiniti interaktivnijom. Time bi se zadovoljile potrebe učenika za zanimljivijom i digitalnijom nastavom, ali ujedno se otvaraju nova pitanja, mogućnosti i prilike za dodatan razvoj metodike nastavnih predmeta.

Istraživanjem je utvrđeno da učenici vole slušati glazbu i treba težiti tome da se odabiru kvalitetna i učenicima zanimljiva glazbena djela kako bi im se razvila ljubav prema glazbi i moguća motivacija za buduće bavljenje glazbom. Istraživanjem se može koristiti kao polazištem za daljnje istraživanje razine motivacije i stvarnoga utjecaja digitalnoga alata na poboljšanje rezultata učenika i aktivnije slušanje glazbe.

Rad također nastoji naglasiti potrebu učitelja za kontinuiranim različitim oblicima stručnih usavršavanja i stjecanja kompetencija upravo u području uporabe digitalnih alata. Učitelji nastoje napustiti tradicionalne načine učenja i poučavanja, no zbog manjka stručnih edukacija to ne mogu ostvariti. Kao i učenici učitelji trebaju imati mogućnost za cjeloživotno obrazovanje koje ih priprema za buduće izazove suvremene škole.

Ipak, ni s digitalizacijom ne treba pretjerivati jer su učitelj i živa riječ nezamjenjivi u učionici. Prekomjerno korištenje digitalnim alatima u nastavi može rezultirati negativnim ishodom u kojemu učitelji gube svoj položaj u 
nastavnome procesu. Stoga bi digitalni alati i slična pomagala trebali ostati upravo to - pomagala koje učitelji rabe kako bi razbili monotoniju u učionici, približili nastavne sadržaje, poticali znatiželju učenika i izvodili raznovrsniju nastavu, a sve radi obogaćivanja znanja i napretka učenika.

Strategije i metode poučavanja ponajviše ovise o učitelju, a iz njih proizlaze načini učenja kojima uče učenici. Značajka je 21. stoljeća brzi i nagli rast i razvoj tehnologije, a njezina je primjena sve češće vidljiva u odgojno-obrazovnome procesu koji je njome bitno osuvremenjen. S obzirom na to, danas je uspješan i kvalitetan učitelj onaj koji prihvaća izazove suvremenoga obrazovanja, koji ih provodi na učenicima primjeren način te koji se razvija i usavršava u skladu s njima. (Tomaš, 2018, str. 115)

\section{LITERATURA}

Bognar, L., Matijević, M. (2005). Didaktika. Školska knjiga.

Dobrota, S. (2016). Glazbena nastava i nastavna tehnologija. Zbornik radova Filozofskog fakulteta u Splitu, (6-7), 6-23. https://hrcak.srce.hr/154573

Dobrota, S. (2016). Stavovi studenata prema umjetničkoj glazbi i glazbenoj nastavi. Školski vjesnik, 65 (Tematski broj), 33-47. https://hrcak.srce.hr/160074

Groznik, B. (2021). nastava uz pomoć platforme za učenje Kahoot. Varaždinski učitelj, 4 (6), 190-204. https://hrcak.srce.hr/254553

Lasić-Lazić, J., Špiranec, S. i Banek Zorica, M. (2012). Izgubljeni u novim obrazovnim okruženjima - pronađeni u informacijskom opismenjavanju. Medijska istraživanja. 18 (1), 125-142. https://hrcak.srce.hr/85384

Matasić, I. i Dumić, S. (2012). Multimedijske tehnologije u obrazovanju. Medijska istraživanja, 18 (1), 143-151. https://hrcak.srce.hr/85389

Matijević, M., Topolovčan, T. (2017). Multimedijska didaktika. Školska knjiga.

Milinović, M. (2018). Prisutnost glazbe na društvenim mrežama među gimnazijalcima. U B. Jerković i T. Škojo (ur.), 2. Međunarodni znanstveni i umjetnički simpozijo pedagogiji u umjetnosti - Komunikacija i interakcija umjetnosti i pedagogije. (str. 280-296). Umjetnička akademija u Osijeku.

Mlinarević, V. Borić, E. (2007). Stručni razvoj učitelja kao pretpostavka suvremene škole. U V. Previšić, N. Šoljan i N. Hrvatić (ur.), Prvi kongres pedagoga Hrvatske Pedagogije: prema cjeloživotnom obrazovanju i društvu znanja. (str. 421-431). Hrvatsko pedagogijsko društvo.

Ministarstvo znanosti i obrazovanja (2010). Nacionalni okvirni kurikulum za predškolski odgoj i obrazovanje te opće obvezno i srednjoškolsko obrazovanje. Republika Hrvatska, Ministarstvo znanosti i obrazovanja.

http://mzos.hr/datoteke/Nacionalni_okvirni_kurikulum.pdf

Ministarstvo znanosti i obrazovanja (2006). Nastavni plan i program za osnovnu školu.

Republika Hrvatska, Ministarstvo znanosti i obrazovanja.

https://narodne-novine.nn.hr/clanci/sluzbeni/2006_09_102_2319.html 
Negulić, T. (2015). Kahoot - sustav za odgovaranje $i$ kvizove. Hrvatska akademska $\mathrm{i}$ istraživačka mreža - CARNET. https://e-laboratorij.carnet.hr/ kahoot-game-based-sustav-za-odgovaranje-i-kvizove/

Nikolić, D. Havzi, S. Narandžić, D. Dakić, D. i Janković, A. (2020). Inovativne metode učenja u visokom obrazovanju integracijom softverskog alata Kahoot!. U V. Katić (ur.), 26. skup Trendovi razvoja: Inovacije u modernom obrazovanju. (str. 1-4). Fakultet tehničkih nauka Univerziteta u Novom Sadu. http://www.trend.uns.ac.rs/ stskup/trend_2020/radovi/T1.3/T1.3-13.pdf

Nikolić, D. Lolić, T. Havzi, S. Spasojević, I. Stefanović, D. (2021). Primena softverskih alata baziranih na igri u online okruženju učenja. U V. Katić (ur.), 27. Skup trendovi razvoja: On-line nastava na univerzitetima. (str. 91-94). Fakultet tehničkih nauka Univerziteta u Novom Sadu. http://www.trend.uns.ac.rs/stskup/trend_2021/ radovi/T1.1/T1.1-19.pdf

Novosel, D. (2017). Didaktičko oblikovanje multimedijskog udžbenika u nastavi Glazbene kulture. [doktorska disertacija, Sveučilište u Zagrebu]. Repozitorij Filozofskog fakulteta u Zagrebu. https://core.ac.uk/download/pdf/299373325.pdf Poljak, V. (1990). Didaktika. Školska knjiga.

Puževski, V. (2002). Škola otvorenih vrata. Naklada Slap.

Rojko, P. (2012). Metodika nastave glazbe: teorijsko-tematski aspekti. Sveučilište J. J. Strossmayera, Pedagoški fakultet Osijek.

Sims, Wendy L. (1990). Sound Approaches to Elementary Music Listening. Music Educators Journal. 77(4), 38-42. https://doi.org/10.2307/3397880

Svalina, V. (2015). Kurikulum nastave glazbene kulture i kompetencije učitelja za poučavanje glazbe. Sveučilište J. J. Strossmayera u Osijeku, Fakultet za odgojne i obrazovne znanosti.

Škojo, T., Radočaj-Jerković, A., Milinović, M. (2016). Utjecaj zborskoga pjevanja na razvoj glazbenih preferencija djece predškolske dobi. U R. Jukić, K. Bogatić, S. Gazibara, S. Pejaković, S. Simel, V. Nagy, V. Aniko Campbell-Barr (ur.), Globalne i lokalne perspektive pedagogije. (str. 59-72). Filozofski fakultet u Osijeku.

Šulentić Begić, J. (2012). Otvoreni model glazbene nastave u praksi osnovne škole (Slušanje glazbe i pjevanje). Metodički priručnik za učitelje i studente glazbene kulture, glazbene pedagogije i primarnog obrazovanja. Učiteljski fakultet.

Šulentić Begić, J. i Birtić, V. (2012). Otvoreni model nastave glazbene kulture u primarnom obrazovanju u nekim osječkim osnovnim školama. Tonovi, 60, 72-84. https://www.bib.irb.hr/607445

Šulentić Begić, J., Begić, A. (2013). Glazbene preferencije učenika I. gimnazije u Osijeku. U M. Brekalo, I. Žužul (ur.), Kultura, društvo, identitet-europski realiteti. (str- 844-861). Sveučilište J. J. Strossmayera u Osijeku, Odjel za kulturologiju.

Tomaš, S. (2018). Digitalne tehnologije kao potpora praćenju i vrednovanju. Hrvatska akademska i istraživačka mreža - CARNET.

https://pilot.e-skole.hr/wp-content/uploads/2018/03/Prirucnik_Digitalne-tehnologijekao-potpora-pracenju-i-vrednovanju.pdf 
Vidulin, S. (2013). Playing Instrument in the Music Culture Teaching: an Opportunity of Active Perception and Understanding of Music. Glasbeno-pedagoški zbornik, 19, 23-39. https://www.bib.irb.hr/686737?rad=686737

Vidulin, S. i Martinović, V. (2015). Umjetnička glazba i oblikovanje kulturnoga identiteta učenika. Školski vjesnik, 64 (4), 573-588. https://hrcak.srce.hr/153129

Vidulin-Orbanić, S. (2002). Pristup glazbi u prvim školskim godinama. Tonovi, 40 (1), 49-55. https://www.bib.irb.hr/439636

Vidulin-Orbanić, S. i Terzić, V. (2011). Polazište i pristup pjevanju u općeobrazovnoj školi. Metodički ogledi, 18 (2), 137-156. https://hrcak.srce.hr/82321

Zrilić, S. i Marin, K. (2019). Kompetencije u suvremenoj školi - potrebe prakse iz perspektive učitelja. Školski vjesnik, 68. (2.), 389-400. https://hrcak.srce.hr/234953 